\title{
Changes in Interleukin-1 Production of Peritoneal Macrophages during Estrous Cycle in Golden Hamsters
}

\author{
YUTAKA YOSHIDA, YASUHIKO NAKAMURA, NORIHIRO SUGINO, KATSUNORI SHIMAMURA, \\ MIOKO ONO, AND HIROSHI KATO
}

Department of Obstetrics and Gynecology, Yamaguchi University School of Medicine, Ube 755, Japan

\begin{abstract}
The present study demonstrated the change in interleukin-1 (IL-1) production of peritoneal macrophages during the estrous cycle in golden hamsters and discussed its possible roles in ovarian function. Macrophages were collected from the peritoneal cavity at $0900 \mathrm{~h}$ on various days of the estrous cycle and incubated for $6 \mathrm{~h}$ in the presence of ovine pituitary LH $(500 \mathrm{ng} / \mathrm{ml})$. The IL-1 concentration in the media was measured by bioassay with the A375S2 human melanoma cell line. The number of macrophages significantly $(P<0.01)$ increased on estrus and proestrus compared with diestrus 1 or diestrus 2. LH-induced production of IL-1 was also greater $(P<0.01)$ on proestrus $\left(292 \pm 36 \mathrm{pg} / 10^{6}\right.$ cells $/$ $\mathrm{ml})$ and estrus $\left(222 \pm 30 \mathrm{pg} / 10^{6}\right.$ cells $\left./ \mathrm{ml}\right)$ than on diestrus $1\left(34 \pm 15 \mathrm{pg} / 10^{6}\right.$ cells $\left./ \mathrm{m} l\right)$ or diestrus $2(117 \pm$ $16 \mathrm{pg} / 10^{6}$ cells $/ \mathrm{ml}$ ). To clarify the factor inducing the changes in peritoneal macrophages, hamsters were ovariectomized on diestrus 1 , and 3 weeks later the animals were treated with sc injections of progesterone ( $200 \mu \mathrm{g} /$ day), testosterone (100 $\mathrm{g}$ /day), estradiol (10 $\mu \mathrm{g} /$ day) or sesame oil for three days. The hamsters were killed $24 \mathrm{~h}$ after the last injection, and the number and IL-1 producing capacity of macrophages were determined. The number of macrophages and their response to LH to produce IL-1 were increased significantly $(P<0.01)$ by estradiol treatment but not by progesterone or testosterone treatment. It was concluded that the peritoneal macrophages became more sensitive to $\mathrm{LH}$ to produce IL-1 on proestrus and estrus in cyclic hamsters, and that these changes in macrophages, probably induced by estradiol, would play important roles in ovarian function.
\end{abstract}

Key words: Macrophage, Interleukin-1, LH, Estradiol

(Endocrine Journal 43: 151-156, 1996)

A RECIPROCAL relationship between reproductive events and the immune system has recently been indicated [1, 2]. The macrophage in particular is one of the key factors in the immune system and has been reported to be present in the ovary $[3,4]$ and to play an important role in the ovarian function [5-7]. Interleukin-1 (IL-1), a cytokine secreted by activated macrophages, is involved in ovarian endocrine function [8-11], including LH receptor formation in cultured granulosa cells [12,

Received: July 5, 1995

Accepted: November 12, 1995

Correspondence to: Dr. Hiroshi KATO, Department of Obstetrics and Gynecology, Yamaguchi University School of Medicine, 1144 Kogushi, Ube 755, Japan
13], hyaluronic acid and proteoglycan biosynthesis [14] and in gelatinase accumulation [15]. It is also reported that IL-1 activity in human macrophages is influenced by gonadal steroids [16]. A previous report from our laboratory also demonstrated that IL-1 stimulates progesterone production in preovulatory follicles, but not in preantral follicles, indicating a stage specific effect of IL-1 during follicular maturation [10]. In this study, we investigated the changes in the number and IL1 production of peritoneal macrophages during the estrous cycle in hamsters, and discussed their roles in ovarian function. 


\section{Materials and Methods}

\section{Animals}

Adult female golden hamsters weighing 80-110 $\mathrm{g}$ (closed colony, SLC Inc., Shizuoka, Japan) were maintained in a $25 \pm 1{ }^{\circ} \mathrm{C}$ room on a 14-h light, 10$\mathrm{h}$ dark schedule (lights on at $0500 \mathrm{~h}$ ). Food and water were provided ad libitum. Hamsters were used in the experiments only after exhibiting 3 consecutive 4-day estrous cycles. Ovulation was defined by the characteristic vaginal discharge.

\section{Materials}

Eagle's minimum essential medium (Eagle's MEM) was purchased from Life Technologies, Inc.-Gibco Products (Grand Island, NY) and supplemented with $2 \mathrm{mM}$ L-glutamine, non-essential amino acids and $60 \mu \mathrm{g} / \mathrm{ml}$ kanamycin. RPMI-1640 medium and Ficoll-Paque were obtained from Flow Laboratories Inc. (McLean, VA). Bovine serum albumin (BSA, fraction V), ovine LH and FSH were purchased from Sigma Chemical Co. (St. Louis, MO). Calf serum newborn (CS) was purchased from Bio. Whittaker, Inc. (Walkersville, MD). Recombinant human IL-1 $\beta\left(5 \times 10^{8}\right.$ $\mathrm{IU} / \mathrm{mg}$ ) was purchased from Genzyme Co. (St. Louis, MO).

\section{Preparation of peritoneal macrophages}

Peritoneal macrophages were prepared in a manner similar to that reported previously [5]. Briefly, cyclic hamsters were decapitated under ether anesthesia at $0900 \mathrm{~h}$ on various days of the estrous cycle and the trunk blood was drawn. Twelve $\mathrm{ml}$ of Hank's balanced salt solution containing $10 \mathrm{IU} /$ $\mathrm{m} l$ heparin was injected into the peritoneal cavity, and after gentle agitation of the abdomen, peritoneal fluid $(10 \mathrm{ml})$ was collected with an 18-gauge needle syringe. The cell suspension was washed twice with cold $0.05 \mathrm{M}$ phosphate buffered saline (PBS) and resuspended in $2.5 \mathrm{ml}$ cold PBS. The cell suspension was loaded onto $2.5 \mathrm{~m} l$ Ficoll-Paque and centrifuged at $400 \times \mathrm{g}$ for $30 \mathrm{~min}$ at room temperature. The mononuclear cell layer was carefully aspirated with a Pasteur pipette and washed twice with cold PBS by centrifuging at $200 \times g$ for $10 \mathrm{~min}$. The pellet was resuspended in $10 \mathrm{ml}$ RPMI-
1640 medium, and placed in a $90 \times 10 \mathrm{~mm}$ glass dish to allow the macrophages to adhere. The nonadhering cells were removed by washing with PBS. The adhering cells, defined as macrophages [5], were scraped off with a rubber policeman, washed with cold PBS and resuspended in RPMI-1640 medium.

\section{In vitro incubation of peritoneal macrophages}

The number of macrophages was adjusted to $1.0 \times$ $10^{6}$ viable cells $/ \mathrm{ml}$ in RPMI-1640 medium, and 1 $\mathrm{m} l$ of cell suspension was planted into each well of a 24-well plastic plate in triplicate. After preincubation for $1 \mathrm{~h}$, the medium was exchanged for fresh Eagle's MEM containing 10\% CS and $500 \mathrm{ng} /$ $\mathrm{m} l \mathrm{LH}$. The addition of $500 \mathrm{ng} / \mathrm{m} l \mathrm{LH}$ is essential in our pilot study for the peritoneal macrophages to release detectable IL-1 into the medium (Table 1). After incubation for $6 \mathrm{~h}$ under $95 \%$ air: $5 \% \mathrm{CO}_{2}$ at $37^{\circ} \mathrm{C}$, the medium was centrifuged at $200 \times \mathrm{g}$ for $10 \mathrm{~min}$, and the supernatant was saved at $-20^{\circ} \mathrm{C}$ for IL-1 bioassay.

\section{IL-1 bioassay}

IL-1 activity was determined by a cytotoxicity assay with an IL-1-sensitive human melanoma cell line A375S2 (ATCC, CRL-1872) [17]. Eagle's MEM supplemented with $10 \%$ CS was used as a basic medium in this assay. $0.1 \mathrm{~m} l$ of the IL- $1 \beta$ standards or test samples were placed into a 96-well plastic plate in triplicate and A375S2 cells $\left(2 \times 10^{3}\right.$ cells in $0.1 \mathrm{ml}$ ) were added to each well. After 96 $\mathrm{h}$ incubation under $95 \%$ air: $5 \% \mathrm{CO}_{2}$ at $37^{\circ} \mathrm{C}, 0.05 \%$ neutral-red dye $(50 \mu l)$ was added to each well and incubation was continued for $2 \mathrm{~h}$. After washing the plate with PBS, $0.1 \mathrm{ml}$ of $50 \%$ ethanol in $0.05 \mathrm{M} \mathrm{NaH}_{2} \mathrm{PO}_{4}$ was added to each well to extract the dye incorporated in the viable cells. The amount of dye was determined by measuring the absorbance at $540 \mathrm{~nm}$ with a multiwell scanning spectrophotometer (MPR A4i, TOSOH Co., Japan). The growth inhibitory activity was expressed as pg IL- $1 / \mathrm{ml}$. The minimal amount of IL-1 detectable by the assay was $12 \mathrm{pg} \mathrm{IL-}-1 / \mathrm{ml}$, and the linear standard line was drawn from $15 \mathrm{pg} / \mathrm{ml}$ to 500 $\mathrm{pg} / \mathrm{ml}$. The other characterizations of this bioassay have been published previously [17]. 


\section{Gonadal steroids injection for ovariectomized hamsters}

Cyclic hamsters were ovariectomized under ether anesthesia between 1000 and $1100 \mathrm{~h}$ on diestrus 1 . Three weeks later, the animals were divided into four groups and received sc injection of either progesterone (200 $\mu \mathrm{g} / \mathrm{animal}$, once a day for 3 days), testosterone (100 $\mu \mathrm{g} / \mathrm{animal}$, once a day for 3 days), estradiol ( $10 \mu \mathrm{g} /$ animal, once a day for 3 days) or sesame oil. Each hamster was decapitated under ether anesthesia $24 \mathrm{~h}$ after the last injection. Peritoneal macrophages were collected, and evaluated for their number and IL-1 producing capacity.

\section{Statistics}

Data were analyzed by analysis of variance and Duncan's new multiple range test. Differences were considered to be significant at $P<0.05$.

\section{Results}

Effects of LH on IL-1 release from peritoneal macrophages

IL-1 release from peritoneal macrophages was significantly increased by ovine LH dose-dependently (not detected in control, $42 \pm 13 \mathrm{pg} / 10^{6}$ cells / $\mathrm{ml}$ in $100 \mathrm{ng} / \mathrm{ml} \mathrm{LH}, 304 \pm 58 \mathrm{pg} / 10^{6}$ cells $/ \mathrm{ml}$ in $500 \mathrm{ng} / \mathrm{ml} \mathrm{LH}, 536 \pm 60 \mathrm{pg} / 10^{6}$ cells $/ \mathrm{ml}$ in 1000 $\mathrm{ng} / \mathrm{ml} \mathrm{LH} ; \mathrm{n}=3$ ) but not by ovine $\mathrm{FSH}$, estradiol, testosterone or progesterone (Table 1).

\section{Changes in the number and IL-1 production of} peritoneal macrophages during the estrous cycle

The number of peritoneal macrophages was increased more significantly $(P<0.01)$ on proestrus and estrus than on diestrus 1 or diestrus 2 (Fig. 1). Five hundred $\mathrm{ng} / \mathrm{ml}$ of $\mathrm{LH}$ also induced greater $(P<0.01)$ response of IL-1 production in proestrous and estrous macrophages than in diestrous 1 and diestrous 2 macrophages (Fig. 2). The response of diestrous 2 macrophages was significantly $(P<0.05)$ greater than that of diestrous 1 macrophages (Fig. 2).
Table 1. Effects of various hormones on IL-1 release of peritoneal macrophages from proestrous hamsters

\begin{tabular}{lcc}
\hline Hormone & $\begin{array}{c}\text { Hormone concentration } \\
\text { tested in vitro }(\mathrm{ng} / \mathrm{ml})\end{array}$ & IL-1 release \\
\hline LH & $100-1000$ & + \\
FSH & $100-1000$ & - \\
Estradiol & $0.1-10$ & - \\
Testosterone & $0.1-10$ & - \\
Progesterone & $1-50$ & - \\
BSA & $100-1000$ & - \\
\hline
\end{tabular}

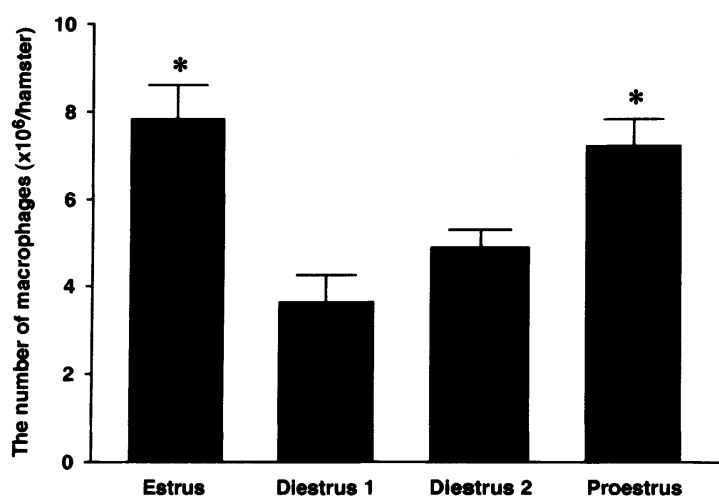

Fig. 1. Changes in the number of peritoneal macrophages during the estrous cycle. Each bar presents the mean \pm SEM for six animals. Data were analyzed by Duncan's new multiple range test. *: $P<0.01$, compared with diestrus 1 and diestrus 2 .

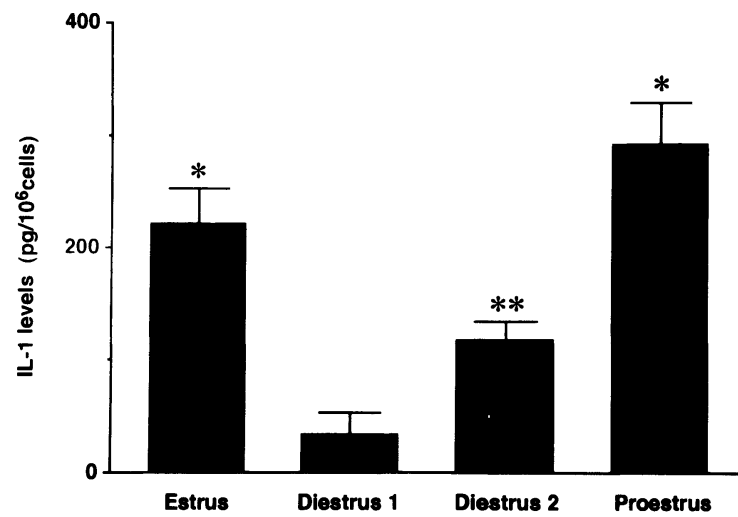

Fig. 2. Changes in IL-1 production of peritoneal macrophages in the presence of LH (500 ng/ $\mathrm{ml}$ ) during the estrous cycle. Each bar presents the mean \pm SEM for the three experiments in triplicate. Data were analyzed by Duncan's new multiple range test. *: $P<0.01$, compared with diestrus 1 and diestrus 2 . $^{* *}: P<0.05$, compared with diestrus 1 . 
Effects of gonadal steroids injections on the number and IL-1 production of peritoneal macrophages in ovariectomized hamsters

Table 2 shows the effects of in vivo injections of various sex steroid hormones on the production of IL-1 in peritoneal macrophages. Both the number and LH-induced production of IL-1 were increased significantly $(P<0.01)$ by estradiol treatment, but not by progesterone or testosterone treatments.

\section{Discussion}

The present study showed that the number of peritoneal macrophages as well as their responsiveness to LH to produce IL-1 were increased on proestrus and estrus during the estrous cycle in hamsters. Recently, estradiol receptors have been demonstrated in human monocytes [18]. Several lines of evidence also suggested that estradiol influences macrophage behavior. For example, the number of macrophages was increased during the process of sexual maturity in immature rats [4]. Maoz et al. [19] also noted that peripheral blood monocyte counts increased during the periods of high circulating estradiol levels, such as the ovulatory period in healthy women. Regarding IL-1 production, Tabibzadeh and Sun [20] showed cyclic changes in IL-1 $\alpha$ gene product in the endometrial epithelium, and suggested that the synthesis and/or secretion of IL-1 may be under the control of systemic steroid signals. The present study clearly demonstrated that estradiol treatment increased the number of peritoneal macrophages and their responsiveness to LH to produce IL-1 (Table 2). It is therefore likely that the increase in the number and LH-responsiveness of the peritoneal macrophages on proestrus and estrus would be due to the estrogen surge that generally begins on diestrus 2 and reaches a peak between 1200 and $1400 \mathrm{~h}$ on proestrus in cyclic hamsters [21]. It is curious that these changes in macrophages still remain high on estrus when circulating estradiol levels are already low [21]. The present results that the LH-responsiveness of the macrophages in ovariectomized hamsters was still high $24 \mathrm{~h}$ after the last estradiol injection suggested that these changes in macrophages induced on proestrus may be maintained until estrus. Serum LH levels are generally increased at $1600 \mathrm{~h}$ on proestrus but rapidly decline thereafter [22]. In addition to this, $\mathrm{LH}$ was the only hormone, at least among the hormones tested in the present study, that stimulated IL-1 production in the macrophages. The physiological significance of the high LH-responsiveness of macrophages on estrus therefore remains unclear.

Regarding the physiological role of IL- 1 in ovarian function, it has been demonstrated that IL-1 stimulates the thecal progesterone production of preovulatory follicles in the cyclic hamster [10]. IL-1 also increased the productions of prostaglandins [11], hyaluronic acid and proteoglycan [14] and gelatinase [15], which may be related to changes associated with the ovulatory process. In fact, IL- $1 \beta$ stimulated ovulation in rabbits [23], and an anti-ovulatory effect of IL-1 receptor antagonist was demonstrated in rats [24, 25], but the effect of IL-1 on ovarian functions is dependent on the stage of follicular development. For example, IL-1 inhibit-

Table 2. The number and IL-1 production in the presence of LH $(500 \mathrm{ng} /$ $\mathrm{ml}$ ) of peritoneal macrophages in ovariectomized hamsters receiving estradiol ( $10 \mu \mathrm{g} /$ body), testosterone ( $100 \mu \mathrm{g} /$ body), progesterone (200 $\mu \mathrm{g} /$ body) or sesame oil alone once a day for three days

\begin{tabular}{lccc}
\hline Group & & $\begin{array}{c}\text { Number of macrophages } \\
\left(\times 10^{6} / \text { hamster }\right)\end{array}$ & $\begin{array}{c}\text { IL-1 levels } \\
\left(\mathrm{pg} / 10^{6} \text { cells }\right)\end{array}$ \\
\hline Control group & $\mathrm{n}=6$ & $7.74 \pm 0.62$ & N.D. \\
Estradiol group & $\mathrm{n}=6$ & $11.72 \pm 0.93^{*}$ & $185 \pm 21$ \\
Testosterone group & $\mathrm{n}=3$ & $6.10 \pm 1.05$ & N.D. \\
Progesterone group & $\mathrm{n}=3$ & $6.78 \pm 0.78$ & N.D. \\
\hline
\end{tabular}

Values are the mean \pm SEM for three or six animals. N.D. means not detectable by this bioassay. The data were analyzed by Duncan's new multiple range test. *: $P<0.01$, compared with the control group. 
ed progesterone production [8] or LH receptor formation in medium-sized follicles [13] in the pig. We found that macrophages stimulated the production of progesterone and testosterone, but not of estradiol, in preovulatory follicles (data not shown). These changes in steroidogenesis are not typical of the ovulatory or luteinizing process but somewhat resemble atretic changes, because it is known that C17-20 lyase is a pivotal enzyme controlled by $\mathrm{LH}$ in the preovulatory follicles of the hamster [26]. Nakamura et al. [10] has suggested that IL-1 would induce atretic changes in follicular development in hamsters. The major objection to this, however, would be that the selected preovulatory follicle should not undergo atresia. Further studies will be necessary to get the whole picture of the physiological roles of IL-1 in follicular development, ovulation, atresia and corpus luteum formation.

In summary, the present results demonstrated that the number and IL-1 production of peritoneal macrophages were increased by estradiol on proestrus and estrus in hamsters, which affected at least the steroidogenesis of the preovulatory follicles.

\section{Acknowledgment}

This work was supported in part by grants (05771252, 06771339) for scientific research from the Ministry of Education, Science and Culture of Japan (Y.N.). The IL-1-sensitive human melanoma cell line A375S2 (ATCC, CRL-1872) was kindly provided by Dr. S. Nakai (Otsuka Pharmaceutical Co. Ltd., Tokushima, Japan). Progesterone (GDN 337), testosterone (GDN 250) and estradiol (GDN 244) antisera were kindly provided by Dr. Gordon D. Niswender (Colorado State University, Fort Collins, $\mathrm{CO}$ ).

\section{References}

1. Adashi EY (1990) The potential relevance of cytokines to ovarian physiology: The emerging role of resident ovarian cells of the white blood cell series. Endocrine Rev 11: 454-464.

2. Norman RJ, Brannstrom M (1994) White cells and the ovary-incidental invaders or essential effectors? J Endocrinol 140: 333-336.

3. Hume DA, Halpin D, Charlton H, Gordon S (1984) The mononuclear phagocyte system of the mouse defined by immunohistochemical localization of antigen F4/80: Macrophages of endocrine organs. Proc Natl Acad Sci USA 81: 4174-4177.

4. Brännström M, Mayrhofer G, Robertson SA (1993) Localization of leukocyte subsets in the rat ovary during the periovulatory period. Biol Reprod 48: 277-286.

5. Halme J, Hammond MG, Syrop CH, Talbert LM (1985) Peritoneal macrophages modulate human granulosa-luteal cell progesterone production. $J$ Clin Endocrinol Metab 61: 912-916.

6. Naito K, Takahashi M (1988) The effects of peritoneal macrophages on monolayered luteal cell progestin secretion in the rat. Endocrinol Japon 35: 439-446.

7. Fukumatsu Y, Katabuchi H, Naito M, Takeya M, Takahashi K, Okamura H (1992) Effect of macrophages on proliferation of granulosa cells in the ovary in rats. J Reprod Fertil 96: 241-249.

8. Fukuoka M, Yasuda K, Taii S, Takakura K, Mori T
(1989) Interleukin-1 stimulates growth and inhibits progesterone secretion in cultures of porcine granulosa cells. Endocrinology 124: 884-890.

9. Gottschall PE, Katsuura G, Arimura A (1989) Interleukin-1 suppresses follicle-stimulating hormone-induced estradiol secretion from cultured ovarian granulosa cells. J Reprod Immunol 15: 281290.

10. Nakamura Y, Kato H, Terranova PF (1990) Interleukin-1 $\alpha$ increases thecal progesterone production of preovulatory follicles in cyclic hamsters. Biol Reprod 43: 169-173.

11. Brännström M, Wang L, Norman RJ (1993) Effects of cytokines on prostaglandin production and steroidogenesis of incubated preovulatory follicles of the rat. Biol Reprod 48: 165-171.

12. Gottschall PE, Katsuura G, Hoffmann ST, Arimura A (1988) Interleukin 1: An inhibitor of luteinizing hormone receptor formation in cultured rat granulosa cells. FASEB J 2: 2492-2496

13. Yasuda K, Fukuoka M, Taii S, Takakura K, Mori T (1990) Inhibitory effects of interleukin-1 on follicle stimulating hormone induction of aromatase activity, progesterone secretion, and functional luteinizing hormone receptors in cultures of porcine granulosa cells. Biol Reprod 43: 905-912.

14. Kokia E, Hurwitz A, Ben-Shlomo I, Adashi EY, Yanagishita M (1993) Receptor-mediated stimulatory effect of IL-1 $\beta$ on hyaluronic acid and 
proteoglycan biosynthesis by cultured rat ovarian cells: Role for heterologous cell-cell interactions. Endocrinology 133: 2391-2394.

15. Hurwitz A, Dushnik M, Solomon H, Ben-Chetrit A, Finci-Yeheskel Z, Milwidsky A, Mayer M, Adashi EY, Yagel S (1993) Cytokine-mediated regulation of rat ovarian function: Interleukin-1 stimulates the accumulation of a 92-kilodalton gelatinase. Endocrinology 132: 2709-2714.

16. Polan ML, Daniele A, Kuo A (1988) Gonadal steroids modulate human monocyte interleukin-1 (IL-1) activity. Fertil Steril 49: 964-968.

17. Nakai S, Mizuno K, Kaneta M, Hirai Y (1988) A simple, sensitive bioassay for the detection of interleukin-1 using human melanoma A375 cell line. Biochem Biophys Res Commun 154: 1189-1196.

18. Wada K, Itoh M, Nakagawa R, Misao R, Mori H, Tamaya T (1992) Estrogen binding sites in peripheral blood monocytes and effects of danazol on their sites in vitro. Gen Pharmacol 23: 693-700.

19. Maoz H, Kaiser N, Halimi M, Barak V, Haimovitz A, Weinstein D, Simon A, Yagel S, Biran S, Treves AJ (1985) The effect of estradiol on human myelomonocytic cells. 1. Enhancement of colony formation. J Reprod Immunol 7: 325-335.

20. Tabibzadeh S, Sun XZ (1992) Cytokine expression in human endometrium throughout the menstrual cycle. Human Reprod 7: 1214-1221.

21. Saidapur SK, Greenwald GS (1978) Peripheral blood and ovarian levels of sex steroids in the cyclic hamster. Biol Reprod 18: 401-408.

22. Bast JD, Greenwald GS (1974) Serum profiles of follicle-stimulating hormone, luteinizing hormone and prolactin during the estrous cycle of the hamster. Endocrinology 94: 1295-1299.

23. Takehara $Y$, Dharmarajan AM, Kaufman G, Wallach EE (1994) Effect of interleukin- $1 \beta$ on ovulation in the in vitro perfused rabbit ovary. Endocrinology 134: 1788-1793.

24. Peterson CM, Hales HA, Hatasaka $\mathrm{HH}$, Mitchell MD, Rittenhouse L, Jones KP (1993) Interleukin-1 $\beta$ $(\mathrm{IL}-1 \beta)$ modulates prostaglandin production and the natural IL-1 receptor antagonist inhibits ovulation in the optimally stimulated rat ovarian perfusion model. Endocrinology 133: 2301-2306.

25. Simón C, Tsafriri A, Chun SY, Piquette GN, Dang W, Polan ML (1994) Interleukin-1 receptor antagonist suppresses human chorionic gonadotropin-induced ovulation in the rat. Biol Reprod 51: 662-667.

26. Hubbars CJ, Greenwald GS (1982) Cyclic nucleotides, DNA, and steroid levels in ovarian follicles and corpora lutea of the cyclic hamster. Biol Reprod 26: $230-240$. 